\title{
Low-dose irradiation of mouse embryos increases Smad-p21 pathway activity and preserves pluripotency
}

\author{
Masami Hayashi ${ }^{1} \cdot$ Kayo Yoshida $^{2} \cdot$ Kohei Kitada $^{1} \cdot$ Akane Kizu $^{2} \cdot$ Daisuke Tachibana $^{1} \cdot$ Mitsuru Fukui $^{3}$. \\ Takashi Morita $^{2} \cdot$ Masayasu Koyama $^{1}$
}

Received: 18 December 2017 / Accepted: 5 March 2018 / Published online: 16 March 2018

(C) The Author(s) 2018

\begin{abstract}
Purpose To study the outcomes of mouse preimplantation embryos irradiated with low doses of X-rays ( $\leq 1 \mathrm{~Gy})$ and investigate apoptosis and pluripotency of the irradiated embryos.

Methods Mouse embryos at the 2-cell stage were collected for in vitro culture. After reaching the 8-cell stage, embryos were irradiated with various low doses of X-rays $(0-1 \mathrm{~Gy})$. Blastocysts with a normal appearance were transferred into a pseudopregnant uterus. The developmental rate to blastocysts and the survival rate following embryo transfer were examined. Expression levels of p21, Smad2, Foxo1, Cdx2, Oct4, and Nanog genes were measured by RT-PCR. Apoptotic cells in mouse blastocysts were examined immunofluorescently by staining for cleaved caspase-3.

Results More than $90 \%$ of non-irradiated and low-dose X-ray-irradiated preimplantation embryos developed to morphologically normal blastocysts that could be implanted and survive in the uterus. However, embryos irradiated with X-rays had more apoptotic cells in a dose-dependent manner. Expression of p21, Smad2, and Foxo1 genes in X-ray-irradiated embryos was increased significantly, while expression of $\mathrm{Cdx} 2$, Oct4, and Nanog genes was maintained in comparison with non-irradiated embryos.

Conclusions Although irradiated embryos contained apoptotic cells, the low doses of irradiation did not disturb development of 8-cell stage embryos to blastocysts or their survival in utero. The underlying mechanisms might involve anti-apoptotic systems, including the Smad-p21 pathway, and preservation of pluripotency.
\end{abstract}

Keywords Preimplantation embryo development $\cdot$ X-ray irradiation $\cdot$ Apoptosis $\cdot$ Pluripotency $\cdot$ Embryo culture

\section{Introduction}

Radiation is indispensable for the diagnosis of diseases. Imaging techniques, such as X-rays, computed tomographic

Electronic supplementary material The online version of this article (https://doi.org/10.1007/s10815-018-1156-y) contains supplementary material, which is available to authorized users.

Kayo Yoshida

k-yoshida@med.osaka-cu.ac.jp

1 Department of Obstetrics and Gynecology, Osaka City University, Graduate School of Medicine, 1-4-3 Asahimachi, Abeno-ku, Osaka 545-8585, Japan

2 Department of Molecular Genetics, Osaka City University, Graduate School of Medicine, 1-4-3 Asahimachi, Abeno-ku, Osaka 545-8585, Japan

3 Laboratory of Statistics, Osaka City University, Graduate School of Medicine, 1-4-3 Asahimachi, Abeno-ku, Osaka 545-8585, Japan scans, and position emission tomography, are widely used in clinical practice [1,2]. Radiation is also applied for therapeutic methods including anti-oncogenic treatment of various organs [3]. However, clinicians should keep in mind that women of fertile age have the potential to carrying children and should consider the so called ten days rule after menstruation when using radiation techniques for diagnosis and/or treatment.

Irradiated preimplantation embryos either die or survive without any detectable malformation [4], and the effect of irradiation on an embryo depends on both the embryo stage and exposure dose [5]. When the fetal radiation dose is less than $0.05 \mathrm{~Gy}$, non-carcinogenic risk such as abortion and malformation is negligible. The effect of a fetal dose of less than 0.1 Gy will be clinically not detectable [6] It has been suggested that minimal threshold of the central nervous system may be 0.06-0.3 Gy [7]. Excess of 1-Gy exposure during embryogenesis will result in clinically significant fetal 
damage. Exposition dose by typical imaging of a single phase of pelvic CT scan would reach 0.01-0.05 Gy and the level will not be considered as a reason to terminate pregnancy [6]. However, several times of examination of mixed Xirradiation will possibly come over $0.1 \mathrm{~Gy}$ and radiation effect may be not negligible. So, we studied the embryonic effects of 0 and $0.1-1.0$ Gy by X-irradiation in the molecular level.

In response to double-strand breaks of DNA induced by radiation, ATM (ataxia telangiectasia mutated) is recruited to phosphorylate the tumor suppressor protein $\mathrm{p} 53[7,8]$. Phosphorylated p53 coordinates cell cycle arrest and apoptosis. In cell cycle arrest, p53 upregulates p21, a cyclindependent kinase (CDK) inhibitor [9]. p21 suppresses cyclin/CDK activity and binds to proliferating cell nuclear antigen, resulting in cell cycle arrest at G1 and G2 [10-12]. When the level of DNA damage is severe, unrepaired doublestrand breaks (DSBs) can lead to apoptosis by p53transcriptional regulation of genes with apoptotic activity [13].

Embryonic stem cells (ESCs), which are derived from the inner cell mass (ICM) of blastocysts, can undergo unlimited self-renewal and retain pluripotency to differentiate into all cell types of the body [14]. In contrast to somatic cells, which activate G1/S, intra S, and G2/M checkpoints after DSBs, ESCs lack the G1/S checkpoint and undergo only a temporary delay at G2/M phase in response to DSBs [15]. This property is thought to be a reason why ESCs are highly sensitive to radiation. Recent studies suggest that p21 might be involved in the apoptotic process of ESCs after radiation exposure, and p21 is activated through Smad and Forkhead box, class O (Foxo) pathways [16-19].

Despite the accumulated data from irradiated ESCs, we still lack information regarding effects of low-dose irradiation on embryos in terms of clinical medicine. Using 8-cell stage mouse embryos irradiated with a low dose (0.1-1.0 Gy), we aimed to (1) observe the developmental rate and survival rate after embryo transfer, (2) investigate the apoptotic process including the Smad-p21 pathway, and (3) evaluate the pluripotency of the ICM and trophectoderm (TE).

\section{Materials and methods}

\section{Animals and embryos}

Mice were maintained according to the Osaka City University guidelines for animal experimentation. BDF1 mice aged 810 weeks were superovulated by an intraperitoneal injection of 6.7 IU pregnant mare serum gonadotropin (PMSG; serotoropin, Aska Pharmaceutical Co.). Forty-eight hours after PMSG injection, the mice were injected with 6.7 IU human chorionic gonadotrophin (hCG; gonadotropin, Aska Pharmaceutical Co.). They were mated with BDF1 males of $>12$ weeks of age. At $42-45 \mathrm{~h}$ after hCG injection, 2-cell embryos were collected from the oviducts by puncturing the ampulla portion of the oviduct with a needle in M2-buffered medium under a stereomicroscope. All embryos were cultured in a $100 \mu \mathrm{l}$ drop of M16 medium covered by mineral oil at $37^{\circ} \mathrm{C}$ in a humidified atmosphere with $5 \% \mathrm{CO}_{2}$.

\section{X-ray irradiation}

Twenty-four hours after collection of 2-cell stage embryos, development of the embryos was observed under the stereomicroscope. Embryos that had developed to the 8-cell stage were collected in $100 \mu \mathrm{l} \mathrm{M} 2$ medium. These 8-cell stage embryos were irradiated with X-rays at doses of $0.1,0.5$, and 1.0 Gy with dose rate of $0.7 \mathrm{~Gy} / \mathrm{min}$ by an X-ray irradiation device (MBR-1520A-2; Hitachi Medical Corporation). After X-ray irradiation, the embryos were washed with M16 medium and cultured at $37^{\circ} \mathrm{C}$.

\section{Real-time reverse transcription polymerase chain reaction analysis}

Thirty-three hours after X-ray irradiation, blastocysts with a normal appearance were collected in a pool and their RNA was extracted. More than 80 embryos were prepared for each dose condition (0, 0.1, 0.5, $1 \mathrm{~Gy}$; total $>320$ embryos) and irradiated. The morphologically normal 60 embryos of each dose were divided into three groups with 20 embryos. RNAs were extracted from 20 embryos. These blastocysts were washed in drops of phosphate-buffered saline (PBS) twice. RNA samples were isolated using an RNeasy Micro Kit (QIAGEN) and dissolved in $14 \mu \mathrm{l}$ RNase-free water. The three RNA samples from each radiation condition were used for RT-PCR as triplicate. cDNA was synthesized from $10 \mu \mathrm{l}$ RNA in a $10-\mu 1$ reaction mixture with random primers and reverse transcription reagent using a High-Capacity cDNA Reverse Transcription Kit (Applied Biosystems). mRNA expression was analyzed by TaqMan real-time PCR. Reactions were carried out using TaqMan Gene Expression Master Mix (Applied Biosystems) in a final volume of $20 \mu \mathrm{l}$ and performed in duplicate for each cDNA sample. Primer sets for 18S rRNA (Mm03928990_g1), p21 (Mm01212280_m1), Smad2 (Mm00487530_m1), Foxo1 (Mm00490671_m1), octamer-binding transcription factor 4 (Oct4; Mm03053917_g1), caudal-type homeobox protein 2 (Cdx2; Mm01212280_m1), and Nanog (Mm02019550_s1) were purchased from Applied Biosystems. Amplifications were performed under standard conditions by ABI7500 Fast System.

\section{Immunofluorescence staining}

Embryos were washed, fixed with $4 \%$ paraformaldehyde in PBS for $20 \mathrm{~min}$, permeabilized for $20 \mathrm{~min}$ at room temperature in PBS containing 0.5\% Triton X-100, and then blocked 
in a $3 \mathrm{mg} / \mathrm{ml}$ bovine serum albumin solution for $30 \mathrm{~min}$. They were immunostained with anti- $\gamma \mathrm{H} 2 \mathrm{AX}$ monoclonal antibody (1:1000 dilution, Novus biologicals), or anti-cleaved caspase3 monoclonal antibody (1:400 dilution, Cell Signaling) overnight at $4{ }^{\circ} \mathrm{C}$ and then treated with a secondary antibody conjugated with an Alexa Fluor (goat anti-rabbit IgG secondary antibody, Alexa Fluor 488 conjugate, 1:1000 dilution; Thermo Scientific) and 6-diamidio-2-phyenylindole (DAPI) for $2 \mathrm{~h}$ at room temperature. The embryos were washed and observed under a fluorescence microscope. At least 10 embryos were analyzed for each $(0,0.1,0.5,1 \mathrm{~Gy})$ irradiation.

\section{Implantation into a pseudopregnant uterus}

ICR pseudopregnant mice (8-10 weeks old) at 2 days postcoitum (dpc) were purchased from Japan SLC. Ten blastocysts with a normal appearance at $33 \mathrm{~h}$ after X-ray irradiation were implanted in a pseudopregnant uterus (one side of a bi-corner uterus) using a glass capillary. The pregnant mice were examined at $19 \mathrm{dpc}$. The number of placentas, fetuses, and implantation marks was counted.

\section{Statistical analysis}

Statistical analysis was performed using the exact $t$ test, Student's $t$ test, one-way ANOVA, Williams test, KruskalWallis test, and Shirley-Williams test. $p<0.05$ was considered as significant.

\section{Results}

\section{Most low-dose X-ray-irradiated preimplantation embryos develop to morphologically normal blastocysts in vitro}

A total of $96.1 \%$ of embryos without irradiation ( 0 Gy) developed to normal blastocysts (Table 1). The developmental rates of embryos irradiated with $0.1,0.5$, and 1.0 Gy to normal blastocysts were $92.3,91.4$, and $90.1 \%$, respectively (Table 1 and Fig. 1b). Abnormal embryos that included developmentally delayed embryos by microscopic observation were indicated (Fig. 1a, asterisks). No significant difference was observed in the developmental rates to normal blastocysts by low doses of $\mathrm{X}$-irradiation.

\section{Blastocysts with a normal appearance after $\leq 1$-Gy $\mathrm{X}$-ray irradiation produce fetuses}

To examine whether X-ray-irradiated embryos could develop in the uterus, we transferred 10 embryos that developed normally after X-ray irradiation into a pseudopregnant uterus (one side of the bi-corner uterus). We analyzed five pseudopregnant mice for each group: control and $0.1,0.5$, or $1.0 \mathrm{~Gy}$ irradiated blastocysts. Non-irradiated embryos had a mean implantation number of 8.4 (implantation rate of $86 \%$ ) as judged by the number of placentas and implantation marks with 7.7 becoming fetuses (Table 2). Embryos irradiated with 0.1 Gy had an implantation number of 8.7 with 6.5 becoming fetuses, those irradiated with $0.5 \mathrm{~Gy}$ had an implantation number of 8.6 with 6.0 becoming fetuses, and those irradiated with 1.0 Gy had an implantation rate of 8.1 with 6.7 becoming fetuses (Table 2). The irradiated embryos had implantation and fetal development rates similar to those of non-irradiated embryos.

\section{One-Gy irradiation induces DNA damage in embryos}

To determine the effect of low-dose irradiation (1 Gy), we evaluated DNA damage in morphologically normal blastocysts. Immunofluorescence staining by $\gamma \mathrm{H} 2 \mathrm{AX}$ revealed that at the blastocyst stage, the embryos without $\mathrm{X}$ irradiation showed low staining by $\gamma \mathrm{H} 2 \mathrm{AX}$, but at $1 \mathrm{~Gy}$ of irradiated blastocysts, several cells were strongly stained by $\gamma \mathrm{H} 2 \mathrm{AX}$ antibody. The embryos of $1 \mathrm{~h}$ after $\mathrm{X}$ irradiation by 1 Gy were weakly stained by $\gamma \mathrm{H} 2 \mathrm{AX}$
Table 1 Preimplantation embryo development after X-ray irradiation

\begin{tabular}{|c|c|c|c|c|c|}
\hline \multirow{2}{*}{$\begin{array}{l}\begin{array}{l}\text { Irradiation } \\
\text { dose (Gy) }\end{array} \\
0\end{array}$} & \multirow{2}{*}{$\begin{array}{l}\text { Number of embryos } \\
152 \\
(52,40,35,25)^{b}\end{array}$} & \multicolumn{2}{|l|}{$\begin{array}{l}\text { Number of } \\
\text { blastocyst }^{\mathrm{a}}(\%)\end{array}$} & \multicolumn{2}{|c|}{$\begin{array}{l}\text { Number of abnormal } \\
\text { embryos }^{\text {a }}(\%)\end{array}$} \\
\hline & & $\begin{array}{l}146 \\
(49,39,33,25)^{\mathrm{b}}\end{array}$ & $96.1 \%$ & $\begin{array}{l}6 \\
(3,1,2,0)^{\mathrm{b}}\end{array}$ & $3.9 \%$ \\
\hline 0.1 & $\begin{array}{l}143 \\
(52,40,26,25)^{\mathrm{b}}\end{array}$ & $\begin{array}{l}132 \\
(48,35,24,25)^{\mathrm{b}}\end{array}$ & $92.3 \%$ & 11 & $7.7 \%$ \\
\hline 0.5 & $\begin{array}{l}152 \\
(55,40,35,22)^{\mathrm{b}}\end{array}$ & $\begin{array}{l}139 \\
(51,34,33,21)^{\mathrm{b}}\end{array}$ & $91.4 \%$ & $\begin{array}{l}13 \\
(4,6,2,1)^{b}\end{array}$ & $8.6 \%$ \\
\hline 1.0 & $\begin{array}{l}152 \\
(52,40,35,25)^{\mathrm{b}}\end{array}$ & $\begin{array}{l}137 \\
(47,35,32,23)^{\mathrm{b}}\end{array}$ & $90.1 \%$ & $\begin{array}{l}16 \\
(5,2,3,2)^{\mathrm{b}}\end{array}$ & $9.9 \%$ \\
\hline
\end{tabular}

${ }^{\mathrm{a}}$ The difference in the developmental rate was not significant among control, 0.1-, 0.5-, and 1.0-Gy-irradiated embryos by the exact $t$ test

${ }^{\mathrm{b}}$ Each number of embryos of four times experiments 

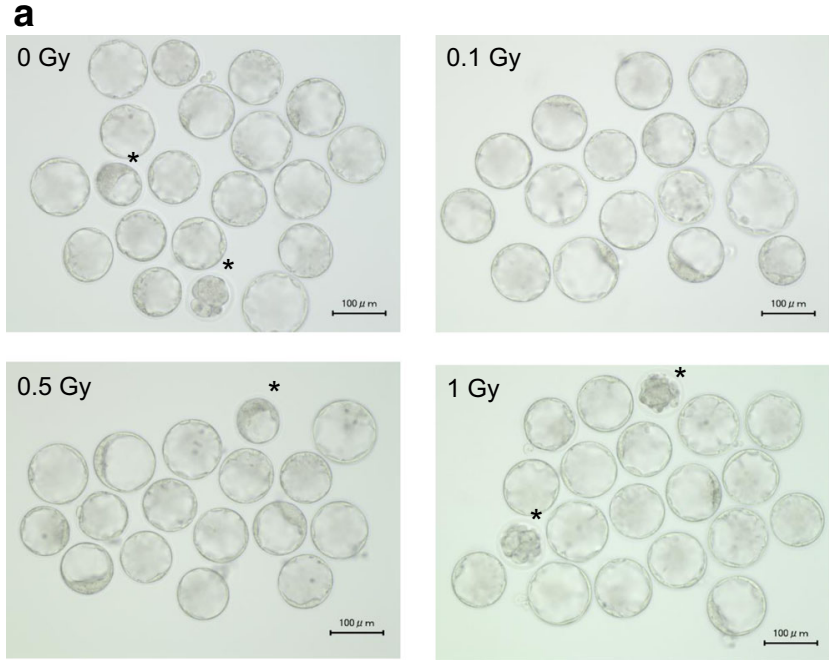

b

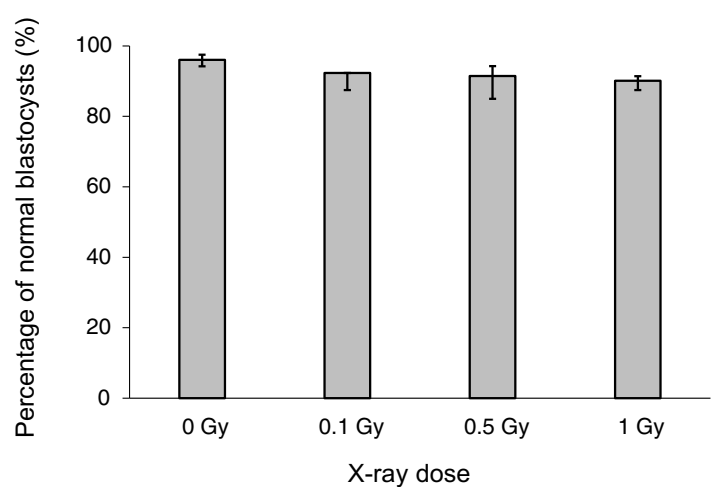

Fig. 1 Development of preimplantation embryos irradiated with X-rays. a Representative micrographs of blastocysts with or without X-ray irradiation $(0.1,0.5$, and $1.0 \mathrm{~Gy})$. Asterisks indicate abnormal blastocysts. b The developmental rate of embryos irradiated with X-rays. Bars represent the maximum and minimum percentage of each experiment

antibody with non-specific signals in the cell surface (Supplemental Fig. 1), while some cells in blastocyst strongly stained after $33 \mathrm{~h}$ of $\mathrm{X}$-irradiation as in Fig. 2. This suggested that the several significantly damaged cells in blastocyst might lead to apoptosis followed by DNA double-strand breaks, resulting in their strong phosphorylation of $\mathrm{H} 2 \mathrm{AX}$.

\section{Low-dose irradiation induces apoptosis in morphologically normal blastocysts}

To determine the effect of low-dose irradiation, we evaluated apoptosis in morphologically normal blastocysts. Immunofluorescence staining of cleaved caspase- 3 revealed that 1-Gy-irradiated embryos displayed more cells with caspase-3 immunoreactivity than non-irradiated embryos in the ICM and TE (Fig. 3a). After 1-Gy irradiation, $27.1 \%$ of blastocysts contained more than five apoptotic cells, $35.6 \%$ contained one to four apoptotic cells, and 37.3\% did not contain any apoptotic cells (Fig. 3b and Table 3). After 0.5-Gy irradiation, $20 \%$ of blastocysts contained more than five apoptotic cells, $38.2 \%$ contained one to four apoptotic cells, and $41.8 \%$ did not contain any apoptotic cells. After 0.1-Gy irradiation, $8.5 \%$ of blastocyst contained more than five apoptotic cells, $35.6 \%$ contained one to four apoptotic cells, and 55.9\% did not contain any apoptotic cells. In non-irradiated blastocysts, $2.6 \%$ of blastocysts contained more than five apoptotic cells, $38.5 \%$ contained one to four apoptotic cells, and 359.0\% did not contain any apoptotic cells. Statistically, we analyzed the distributions by Kruskal-Wallis test and then compared the rates of apoptotic cell-containing cells by Shirley-Williams test. We judged the blastocysts without apoptotic cells were significantly $(p<0.05)$ decreased, when the embryos were irradiated at 0.5 and $1.0 \mathrm{~Gy}$ comparing with $0 \mathrm{~Gy}$. On the contrary, the blastocysts with more than five apoptotic cells were significantly $(p<0.05)$ increased, when the embryos were irradiated at 0.5 and 1.0 Gy comparing with $0 \mathrm{~Gy}$. These results confirmed that 0.5 - and 1-Gy irradiation induced apoptosis in morphologically normal blastocysts.

\section{Gene expression of p21, Smad 2, and Foxo1}

Next, we examined gene expression of $\mathrm{p} 21$, which is related to cell arrest and apoptosis, and Smad 2 and Foxol that upregulate $\mathrm{p} 21$ by RT-PCR. The 8 -cell stage embryos were irradiated and RNAs were extracted from normal blastocysts. We then analyzed p21, Smad 2, and Foxo1. Expression of p21 and Smad 2 genes was increased depending on the dose of irradiation. Normal blastocysts derived from 8-cell stage embryos
Table 2 Pregnancy outcome of irradiation

\begin{tabular}{llll}
\hline $\begin{array}{l}\text { Irradiation } \\
\text { dose }(\mathrm{Gy})\end{array}$ & $\begin{array}{l}\text { Number of } \\
\text { pregnant } \\
\text { mice analyzed }\end{array}$ & $\begin{array}{l}\text { Number of } \\
\text { implantations } \\
\text { (average) }\end{array}$ & $\begin{array}{l}\text { Number of } \\
\text { fetuses }^{\mathrm{a}} \\
\text { (average) }\end{array}$ \\
\hline 0 & 5 & $8.4 \pm 1.6$ & $7.7 \pm 1.6$ \\
0.1 & 5 & $8.7 \pm 1.3$ & $6.5 \pm 2.0$ \\
0.5 & 5 & $8.6 \pm 0.9$ & $6.0 \pm 1.1$ \\
1.0 & 5 & $8.1 \pm 1.3$ & $6.7 \pm 1.9$ \\
\hline
\end{tabular}

${ }^{a}$ There was no significant difference in the number of implantations or fetuses between each group by the exact $t$ test 
Fig. $2 \gamma \mathrm{H} 2 \mathrm{AX}$ expression in blastocysts after X-ray irradiation. Representative images showing the immunofluorescence intensity of $\gamma \mathrm{H} 2 \mathrm{AX}$ (green) in control (0 Gy) and 1-Gy X-ray-irradiated embryos. Merged micrographs show the localization of $\gamma \mathrm{H} 2 \mathrm{AX}$ (green) with DAPI staining (blue)

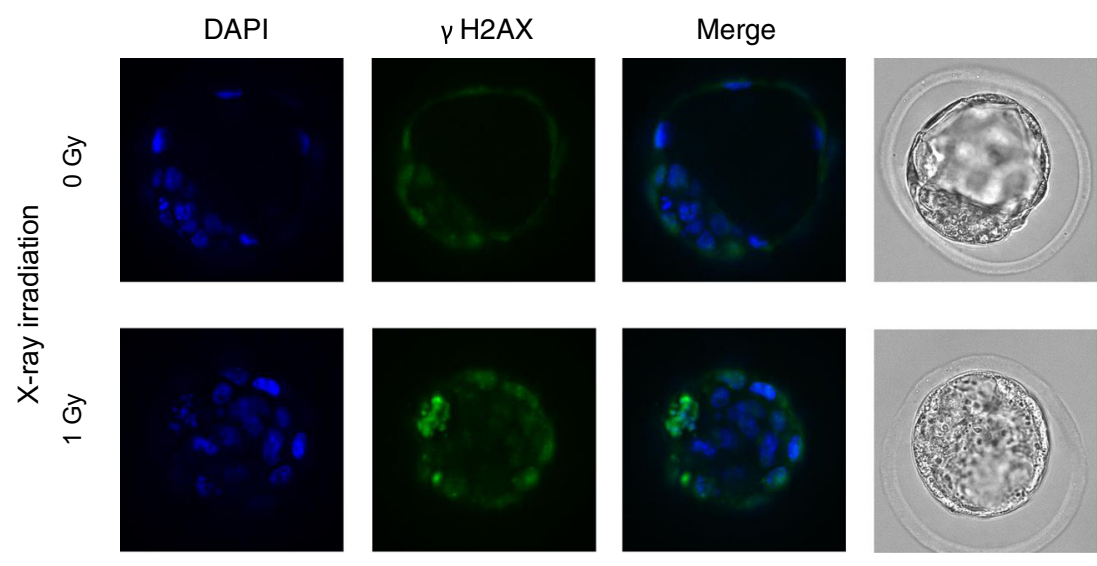

irradiated with X-rays at $0.1 \mathrm{~Gy}$ had increased gene expression of $\mathrm{p} 21$ by 1.4 -fold, compared with non-irradiated embryos (Fig. 4a). Normal blastocysts after X-ray irradiation at 0.5 and 1 Gy had significantly increased gene expression of p21 by 2.1 -fold and 2.5 -fold, respectively, compared with nonirradiated embryos (Fig. 4a). Normal blastocysts derived from 8-cell stage embryos irradiated with X-ray at 0.1 Gy had increased gene expression of Smad 2 by 1.3-fold, compared with non-irradiated embryos (Fig. 3b). The 0.5- and 1-Gy Xray-irradiated normal blastocysts had significantly increased gene expression of Smad 2 by 2.2-fold and 2.8-fold, respectively, compared with non-irradiated embryos (Fig. 4b).
Fig. 3 Cleaved caspase-3

expression in blastocysts after Xray irradiation. a Representative images showing the

immunofluorescence intensity of cleaved caspase-3 (green) in control (0 Gy) and 1-Gy X-rayirradiated embryos. Merged micrographs show the localization of cleaved caspase-3 (green) with DAPI staining (blue). Bar $=20 \mu \mathrm{m}$. b Average percentages of apoptotic cell-containing blastocysts Xirradiated at $0,0.1,0.5$, and $1 \mathrm{~Gy}$ are shown. Bars represent maximum and minimum percentages of each experiment. The immunofluorescence staining was repeated three times using more than 10 blastocysts in each dose
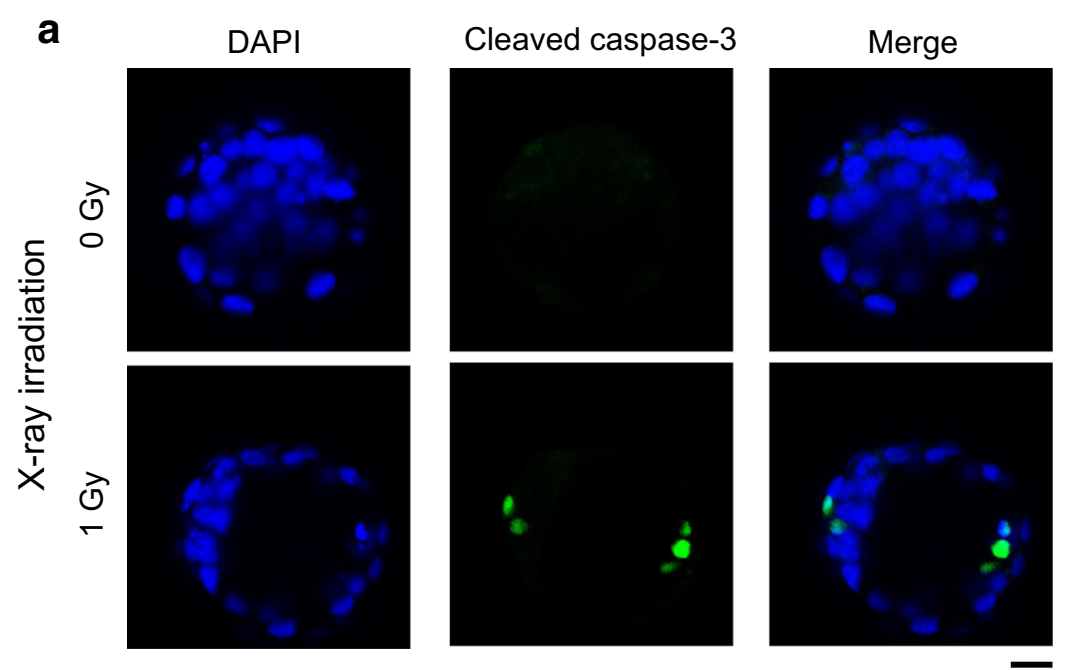

b

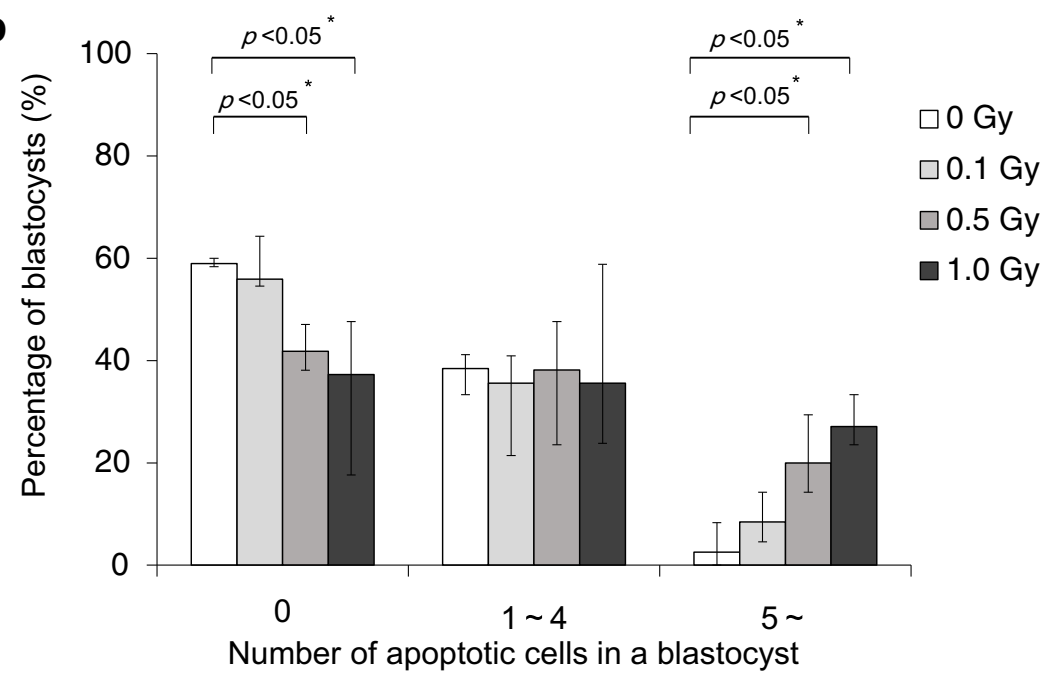


Table 3 Number and percentage of apoptotic cells in a blastocyst

\begin{tabular}{|c|c|c|c|c|c|c|c|}
\hline \multirow[t]{2}{*}{ Irradiation dose (Gy) } & \multicolumn{7}{|c|}{ Number of apoptotic cells in a blastocyst (\%) } \\
\hline & 0 & & $1-4$ & & $>5$ & & Total \\
\hline 0 & $\begin{array}{l}23 \\
(6,10,7)^{\mathrm{a}}\end{array}$ & $59.0 \%$ & $\begin{array}{l}15 \\
(4,7,4)^{\mathrm{a}}\end{array}$ & $38.5 \%$ & $\begin{array}{l}1 \\
(0,0,1)^{\mathrm{a}}\end{array}$ & $2.6 \%$ & $\begin{array}{l}39 \\
(10,17,12)^{a}\end{array}$ \\
\hline 0.1 & $\begin{array}{l}33 \\
(9,12,12)^{\mathrm{a}}\end{array}$ & $55.9 \%$ & $\begin{array}{l}21 \\
(4,9,8)^{\mathrm{a}}\end{array}$ & $35.6 \%$ & $\begin{array}{l}5 \\
(2,1,2)^{\mathrm{a}}\end{array}$ & $8.5 \%$ & $\begin{array}{l}59 \\
(15,22,22)^{\mathrm{a}}\end{array}$ \\
\hline 0.5 & $\begin{array}{l}23 \\
(8,8,7)^{\mathrm{a}}\end{array}$ & $41.8 \%$ & $\begin{array}{l}21 \\
(4,10,7)^{\mathrm{a}}\end{array}$ & $38.2 \%$ & $\begin{array}{l}11 \\
(5,3,3)^{\mathrm{a}}\end{array}$ & $20 \%$ & $\begin{array}{l}55 \\
(17,21,17)^{\mathrm{a}}\end{array}$ \\
\hline 1.0 & $\begin{array}{l}22 \\
(9,10,3)^{\mathrm{a}}\end{array}$ & $37.3 \%$ & $\begin{array}{l}21 \\
(5,6,10)^{\mathrm{a}}\end{array}$ & $35.6 \%$ & $\begin{array}{l}16 \\
(7,5,4)^{\mathrm{a}}\end{array}$ & $27.1 \%$ & $\begin{array}{l}59 \\
(21,21,17)^{\mathrm{a}}\end{array}$ \\
\hline
\end{tabular}

There are significant differences between each group by Kruskal-Wallis test. Blastocysts without apoptotic cells were significantly $(p<0.05)$ decreased, when the embryos were irradiated at 0.5 and 1.0 Gy comparing with 0 Gy by Shirley-Williams test. On the contrary, the blastocysts with more than five apoptotic cells were significantly $(p<0.05)$ increased, when the embryos were irradiated at 0.5 and 1.0 Gy comparing with 0 Gy by ShirleyWilliams test

${ }^{\text {a }}$ Each number of embryos of triplicate experiments
Expression of the Foxol gene tended to increase in a dosedependent manner, but it was not significant (Fig. 4c).

\section{Morphologically normal blastocysts after 1-Gy irradiation maintain developmental pluripotency}

To determine the influence of irradiation on the pluripotency of embryos, we examined the gene expression of Cdx2, Oct4, and Nanog by RT-PCR. Normal blastocysts derived from 8-cell stage embryos irradiated with X-rays at 1 Gy did not show decreases in expression of $\mathrm{Cdx} 2$, Oct4, and Nanog genes (Fig. 4d-f). These results confirmed that the morphologically normal blastocysts retained pluripotency after irradiation at $1 \mathrm{~Gy}$.

\section{Discussion}

More than $90 \%$ of low-dose X-ray-irradiated preimplantation embryos developed into morphologically normal blastocysts that could be implanted and survive in the uterus similarly to non-radiated embryos, even though preimplantation embryos
Fig. 4 RT-PCR analysis of $\mathrm{p} 21$, Smad 2, Foxo1, Oct4, Cdx2, and Nanog mRNAs in blastocysts after low-dose irradiation. RTPCR was conducted using three replicates of RNA samples from 20 X-ray-irradiated blastocysts $(0.1,0.5$, and 1.0 Gy). The relative amount of mRNA was normalized to the $18 \mathrm{~S}$ rRNA level and expressed the fold change compared the control sample. RTPCR was conducted using three replicates of RNA samples. Error bars represent the standard error of the mean. $* p<0.05$ versus control. a p21, b Smad 2, c Foxo1, d Oct4, e Cdx2, and f Nanog
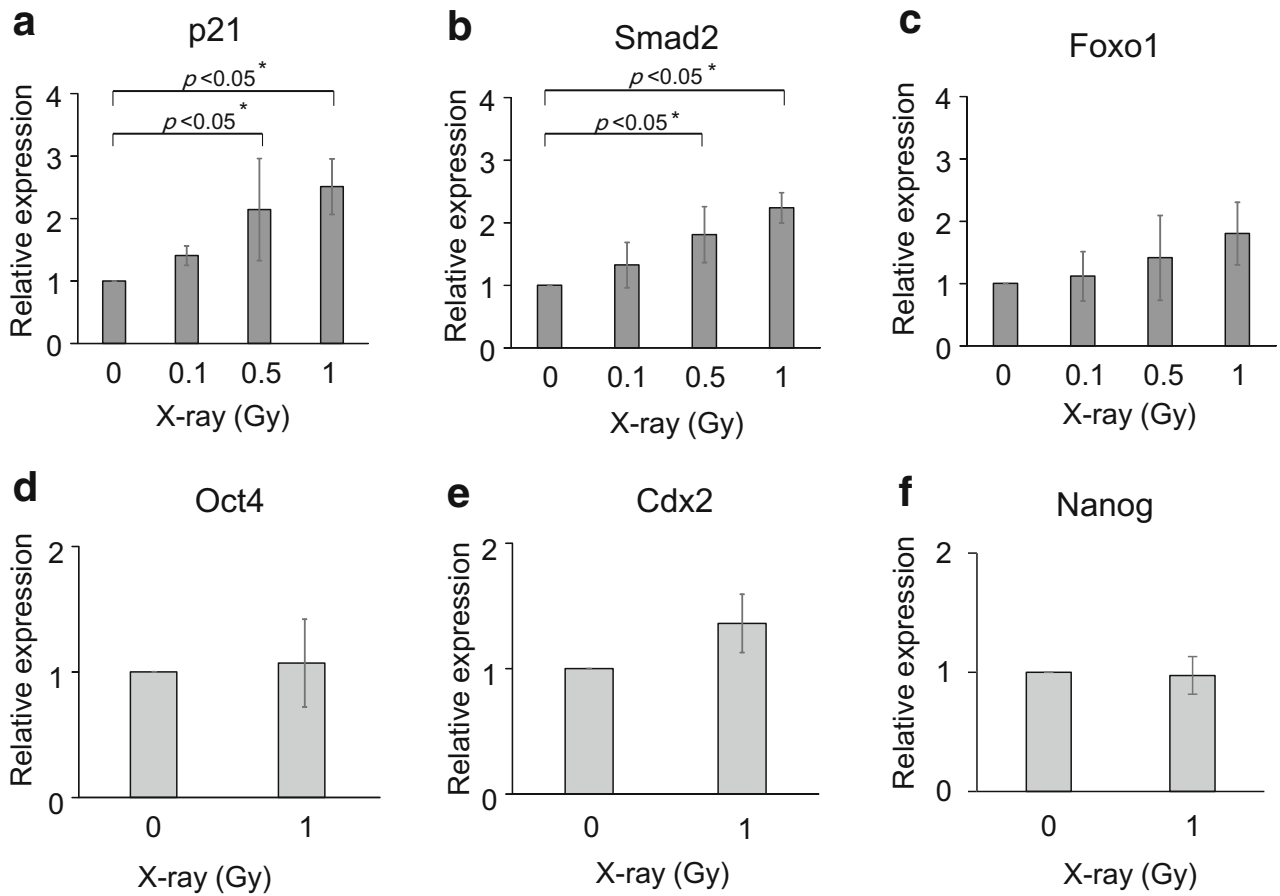
had more apoptotic cells compared with non-radiated embryos. This phenomenon might be due to preserved pluripotency as shown by maintained Oct4 and Nanog expression and increased activity of the Smad-p21 pathway that is thought to act as an anti-apoptotic factor.

Müeller et al. showed that 1-cell embryos had a doseresponse relationship and increased frequency of lethal events (preimplantation deaths, resorptions, and fetal deaths) even at low-dose irradiation ranging from 0.25 to 1 Gy, whereas 32- to 64-cell embryos were unaffected by 1 Gy irradiation [20]. They also showed increased lethality in 32- to 64-cell embryos after 2-Gy irradiation, suggesting that a threshold may exist close to $1 \mathrm{~Gy}$ in multicellular embryos [20]. In frozen 8-cell mouse embryos, Glenister et al. found that even 2-Gy irradiation had no effect on their morphological appearance, development to blastocysts, implantation rate, or ratio of live fetuses to transferred embryos [21]. In this study, we collected and cultured 2-cell stage embryos in vitro and irradiated them with $1 \mathrm{~Gy}$ at the 8-cell stage. We observed that more than $90 \%$ of embryos developed to blastocysts, and the blastocysts successfully implanted and survived in the uterus similar to the control. Taken together with previous reports, our findings suggest that 1-Gy irradiation might have no effect on the development of multicellular embryos in culture and pregnant mice, or even frozen embryos.

p21 was originally thought to play an important role as a cell cycle regulator $[10,12]$. More recently, it was found to play other fundamental roles including modulation of apoptosis [22-24]. Several studies have shown that suppression of p21 induces apoptosis in various human carcinoma cells [23, 24]. In preimplantation embryos, Niwa et al. studied sperm-irradiated embryos that were obtained from nonirradiated female mice mated with irradiated male mice exposed to 6-Gy X-rays [25]. They detected apoptotic cells in the ICM at the early blastocyst stage, but not at earlier stages. In addition, they found that apoptosis was more pronounced in sperm-irradiated $\mathrm{p} 21^{-/-}$embryos than that in wild-type p21 embryos. It was concluded that damage responses in preimplantation embryos occur in a stagespecific manner, and that $\mathrm{p} 21$ is involved in apoptosis at the blastocyst stage [25]. In this study, we first demonstrated an increase in p21 gene expression of low-doseirradiated blastocysts. Considering the evidence reported by Suvorova et al. that $\mathrm{p} 21$ gene transcription increases gradually until day 5 [17], the prolonged effect of p21 might benefit blastocysts that have apoptotic cells to survive in the uterus.

The tumor suppressor gene p53 is a well-known transcriptional regulator of p21 [9]. In somatic cells, DNA damage by radiation upregulates $\mathrm{p} 53$ activity and subsequently results in p21 expression $[9,13,26]$. Norimura et al. reported that, after $\mathrm{X}$-ray irradiation of pregnant mice at 3.5 days after conception (blastocyst stage) with $2 \mathrm{~Gy}, \mathrm{p} 53^{+/+}$mice had no incidence of anomalies and a $73 \%$ incidence of death before completion of the placenta, whereas $\mathrm{p} 53^{-/-}$mice had a $22 \%$ incidence of anomalies and a $44 \%$ incidence of deaths before completion of the placenta. They suggested that embryos have a p53dependent guardian mechanism that aborts cells bearing radiation-induced teratogenic DNA damage [27]. Furthermore, it has been reported that p21 is activated through a p53-independent pathway in somatic cells [28]. Transforming growth factor $\beta$ (TGF- $\beta$ ) is a highly important growth factor in tissues after radiation exposure, which induces p21 through a p53-independent mechanism [29]. TGF- $\beta$ induces upregulation of $\mathrm{p} 21$ via the Smad signaling pathway in response to DNA damage by radiation [18] and Foxo is known to act with TGF- $\beta$-activated Smad [19]. In the mouse embryo, Muñoz-Espin et al. showed that cellular senescence occurs during mouse embryonic development at the mesonephros and the endolymphatic sac of the inner ear. They observed that the senescence was dependent on $\mathrm{p} 21$, but independent of $\mathrm{p} 53$. In addition, they found that the expression of p21 was regulated by TGF- $\beta$ / SMAD and PIK3/FOXO pathways [30]. Our results suggested that low-dose irradiation upregulated the Smad-p21 pathway.

Blastocysts consist of the TE, the single outer cells involved in implantation, which expand to form extraembryonic tissues including the placenta, and the ICM, the inner cells that will develop into pluripotent progenitors of all fetal cell types [31]. Differentiation of the TE and ICM is regulated by several genes. Cdx2 is essential for expansion of the TE lineage [32], whereas Oct4, a member of the POU family of transcription factors and Nanog, a highly divergent homeodomaincontaining protein, maintain pluripotency of the ICM [32-35]. Momcilovic et al. reported that, in human ESCs, a decrease in the mRNA level of Oct4 at $6 \mathrm{~h}$ following 2-Gy irradiation returned to the level observed in non-irradiated cells after $24 \mathrm{~h}$, suggesting that the surviving human ESCs remained pluripotent after irradiation [36]. We showed that expression of Oct4, Cdx2, and Nanog was maintained in irradiated blastocysts at the same level as that in non-irradiated blastocysts. These results suggest that the surviving cells in low-dose-irradiated blastocysts maintain pluripotency of the ICM and the ability to expand the TE.

In conclusion, we showed that low-dose $(0.1-1.0 \mathrm{~Gy})$ irradiation did not disturb development of 8-cell stage embryos to blastocysts that survive in the uterus, even though the irradiated embryos included apoptotic cells in the ICM and TE. The underlying mechanism of our observation might be involved in the anti-apoptotic system including the Smad-p21 pathway as well as preserved pluripotency by $\mathrm{Cdx} 2$ and Oct 4 expression to recover the damage, and develop and survive normally in subsequent embryological steps. These findings may be important for doctors and clinical embryologists in the field of reproductive 
medicine. Our findings are important to understand the mechanism of embryo development after low-dose irradiation and increase our understanding of the "all or none" phenomenon. Further studies are needed to elucidate the effect on malformation, and functional and neurological development of fetuses at risk of irradiation at the embryo stage.

Acknowledgments We thank Mitchell Arico from Edanz Group (www.edanzediting.com/ac) for editing a draft of this manuscript.

\section{Compliance with ethical standards}

Mice were maintained according to the Osaka City University guidelines for animal experimentation.

Open Access This article is distributed under the terms of the Creative Commons Attribution 4.0 International License (http:// creativecommons.org/licenses/by/4.0/), which permits unrestricted use, distribution, and reproduction in any medium, provided you give appropriate credit to the original author(s) and the source, provide a link to the Creative Commons license, and indicate if changes were made.

\section{References}

1. Brenner DJ, Hall EJ. Computed tomography — an increasing source of radiation exposure. N Engl J Med. 2007;357(22):2277-84.

2. Bar-Shalom R, Yefremov N, Guralnik L, Gaitini D, Frenkel A, Kuten A, et al. Clinical performance of PET/CT in evaluation of cancer: additional value for diagnostic imaging and patient management. J Nucl Med. 2003;44(8):1200-9.

3. Connell PP, Hellman S. Advances in radiotherapy and implications for the next century: a historical perspective. Cancer Res. 2009;69(2):383-92.

4. Hall EJ. Scientific view of low-level radiation risks. Radiographics. 1991;11(3):509-18.

5. Adiga SK, Toyoshima M, Shimura T, Takeda J, Uematsu N, Niwa $\mathrm{O}$. Delayed and stage specific phosphorylation of H2AX during preimplantation development of gamma-irradiated mouse embryos. Reproduction. 2007;133:415-22.

6. McCollough CH, Schueler BA, Atwell TD, Braun NN, Regner DM, Brown DL, et al. Radiation exposure and pregnancy: when should we be concerned? Radiographics. 2007;27:909-17.

7. Canman CE, Lim DS, Cimprich KA, Taya Y, Tamai K, Sakaguchi $\mathrm{K}$, et al. Activation of the ATM kinase by ionizing radiation and phosphorylation of p53. Science. 1998;281(5383):1677-9.

8. Burma S, Chen BP, Murphy M, Kurimasa A, Chen DJ. ATM phosphorylates histone $\mathrm{H} 2 \mathrm{AX}$ in response to DNA double-strand breaks. J Biol Chem. 2001;276(45):42462-7.

9. El-Deiry WS, Tokino T, Velculescu VE, Levy DB, Parsons R, Trent $\mathrm{JM}$, et al. WAF1, a potential mediator of $\mathrm{p} 53$ tumor suppression. Cell. 1993;75(4):817-25.

10. Harper JW, Adami GR, Wei N, Keyomarsi K, Elledge SJ. The p21 Cdk-interacting protein Cip1 is a potent inhibitor of G1 cyclindependent kinases. Cell. 1993;75(4):805-16.

11. Cayrol C, Knibiehler M, Ducommun B. p21 binding to PCNA causes G1 and G2 cell cycle arrest in p53-deficient cells. Oncogene. 1998;16(3):311-20.

12. Niculescu AB III, Chen X, Smeets M, Hengst L, Prives C, Reed SI. Effects of p21(Cip1/Wafl) at both the G1/S and the G2/M cell cycle transitions: $\mathrm{pRb}$ is a critical determinant in blocking DNA replication and in preventing endoreduplication. Mol Cell Biol. 1998;18(1):629-43.

13. Lowe SW, Schmitt EM, Smith SW, Osborne BA, Jacks T. p53 is required for radiation-induced apoptosis in mouse thymocytes. Nature. 1993;362(6423):847-9.

14. Thomson JA, Itskovitz-Eldor J, Shapiro SS, Waknitz MA, Swiergiel JJ, Marshall VS, et al. Embryonic stem cell lines derived from human blastocysts. Science. 1998;282(5391):1145-7.

15. Hong Y, Stambrook PJ. Restoration of an absent G1 arrest and protection from apoptosis in embryonic stem cells after ionizing radiation. Proc Natl Acad Sci U S A. 2004;101(40):14443-8.

16. Sokolov M, Neumann R. Effects of low doses of ionizing radiation exposures on stress-responsive gene expression in human embryonic stem cells. Int J Mol Sci. 2014;15(1):588-604.

17. Suvorova II, Grigorash BB, Chuykin IA, Pospelova TV, Pospelov VA. G1 checkpoint is compromised in mouse ESCs due to functional uncoupling of p53-p21Waf1 signaling. Cell Cycle. 2016;15(1):52-63.

18. Lee J, Kim MR, Kim HJ, An YS, Yi JY. TGF- $\beta 1$ accelerates the DNA damage response in epithelial cells via Smad signaling. Biochem Biophys Res Commun. 2016;476(4):420-5.

19. Seoane J, Le HV, Shen L, Anderson SA, Massagué J. Integration of Smad and forkhead pathways in the control of neuroepithelial and glioblastoma cell proliferation. Cell. 2004;117(2):211-23.

20. Müller WU, Streffer C, Pampfer S. The question of threshold doses for radiation damage: malformations induced by radiation exposure of unicellular or multicellular preimplantation stages of the mouse. Radiat Environ Biophys. 1994;33:63-8.

21. Glenister PH, Whittingham DG, Lyon MF. Further studies on the effect of radiation during the storage of frozen 8-cell mouse embryos at -196 degrees C. J Reprod Fertil. 1984;70(1):229-34.

22. Polyak K, Waldman T, He TC, Kinzler KW, Vogelstein B. Genetic determinants of $\mathrm{p} 53$-induced apoptosis and growth arrest. Genes Dev. 1996;10(15):1945-52.

23. Gorospe M, Wang X, Guyton KZ, Holbrook NJ. Protective role of p21(Wafl/Cip1) against prostaglandin A2-mediated apoptosis of human colorectal carcinoma cells. Mol Cell Biol. 1996;16(12): 6654-60.

24. Gorospe M, Cirielli C, Wang X, Seth P, Capogrossi MC, Holbrook NJ. p21(Waf1/Cip1) protects against p53-mediated apoptosis of human melanoma cells. Oncogene. 1997;14(8):929-35.

25. Adiga SK, Toyoshima M, Shiraishi K, Shimura T, Takeda J, Taga $\mathrm{M}$, et al. p21 provides stage specific DNA damage control to preimplantation embryos. Oncogene. 2007;26(42):6141-9.

26. Abbas T, Dutta A. p21 in cancer: intricate networks and multiple activities. Nat Rev Cancer. 2009;9(6):400-14.

27. Norimura T, Nomoto S, Katsuki M, Gondo Y, Kondo S. p53dependent apoptosis suppresses radiation-induced teratogenesis. Nat Med. 1996;2(5):577-80.

28. Parker SB, Eichele G, Zhang P, Rawls A, Sands AT, Bradley A, et al. p53-independent expression of p21Cip1 in muscle and other terminally differentiating cells. Science. 1995;267(5200):1024-7.

29. Datto MB, Li Y, Panus JF, Howe DJ, Xiong Y, Wang XF. Transforming growth factor beta induces the cyclin-dependent kinase inhibitor p21 through a p53-independent mechanism. Proc Natl Acad Sci U S A. 1995;92(12):5545-9.

30. Muñoz-Espín D, Cañamero M, Maraver A, Gómez-López G, Contreras J, Murillo-Cuesta S, et al. Programmed cell senescence during mammalian embryonic development. Cell. 2013;155(5): 1104-18.

31. Fleming TP. A quantitative analysis of cell allocation to trophectoderm and inner cell mass in the mouse blastocyst. Dev Biol. 1987;119(2):520-31.

32. Strumpf D, Mao CA, Yamanaka Y, Ralston A, Chawengsaksophak $\mathrm{K}$, Beck F, et al. Cdx2 is required for correct cell fate specification 
and differentiation of trophectoderm in the mouse blastocyst. Development. 2005;132(9):2093-102.

33. Palmieri SL, Peter W, Hess H, Schöler HR. Oct-4 transcription factor is differentially expressed in the mouse embryo during establishment of the first two extraembryonic cell lineages involved in implantation. Dev Biol. 1994;166(1):259-67.

34. Nichols J, Zevnik B, Anastassiadis K, Niwa H, Klewe-Nebenius D, Chambers I, et al. Formation of pluripotent stem cells in the mammalian embryo depends on the POU transcription factor Oct4. Cell. 1998;95(3):379-91.
35. Mitsui K, Tokuzawa Y, Itoh H, Segawa K, Murakami M, Takahashi $\mathrm{K}$, et al. The homeoprotein Nanog is required for maintenance of pluripotency in mouse epiblast and ES cells. Cell. 2003;113:63142.

36. Momcilović O, Choi S, Varum S, Bakkenist C, Schatten G, Navara C. Ionizing radiation induces ATM dependent checkpoint signaling and $\mathrm{G}(2)$ but not $\mathrm{G}(1)$ cell cycle arrest in pluripotent human embryonic stem cells. Stem Cells. 2009;27(8):1822-35. 